\title{
Integration of an invasive consumer into an estuarine food web: direct and indirect effects of the New Zealand mud snail
}

\author{
Valance E. F. Brenneis • Andrew Sih • \\ Catherine E. de Rivera
}

Received: 19 May 2010/Accepted: 16 February 2011/Published online: 30 March 2011

(c) The Author(s) 2011. This article is published with open access at Springerlink.com

\begin{abstract}
Introduced species interact both directly and indirectly with native species. We examine interactions between the introduced New Zealand mud snail (Potamopyrgus antipodarum) and native estuarine invertebrates and predators through experiments and field studies. A widely held management concern is that when $P$. antipodarum, which has low nutritional value, becomes abundant, it replaces nutritious prey in fish diets. We tested two key components of this view: (1) that fish consume, but get little direct nutritional value from $P$. antipodarum; and (2) that $P$. antipodarum has an indirect negative effect on fish by reducing the energy derived from native prey. We also examined predation by the native signal crayfish, Pacifastacus leniusculus. Laboratory feeding trials showed that both crayfish and fish consume $P$. antipodarum, a direct effect. Crayfish consumed and successfully digested higher numbers of snails than did fish [Pacific staghorn sculpin (Leptocottus armatus), three spine stickleback (Gasterosteus aculeatus), and juvenile starry flounder (Platicthys stellatus)]. $P$. antipodarum occurred at low frequencies in
\end{abstract}

Communicated by Craig Osenberg.

Electronic supplementary material The online version of this article (doi:10.1007/s00442-011-1962-8) contains supplementary material, which is available to authorized users.

V. E. F. Brenneis $(\bowtie) \cdot$ A. Sih

Department of Environmental Science and Policy, University of California Davis, One Shields Avenue,

Davis, CA 95616, USA

e-mail: valanceb@pdx.edu

V. E. F. Brenneis - C. E. de Rivera

Department of Environmental Science and Management,

Portland State University, P.O. Box 751, Portland,

OR 97207, USA the stomachs of wild-caught fish. More interesting were the indirect effects of this invader, which ran counter to predictions. $P$. antipodarum presence was associated with no change or an increase in the amount of energy derived from native prey by predators. The presence of $P$. antipodarum also led to increased consumption of and preference for the native amphipod Americorophium salmonis over the native isopod Gnorimosphaeroma insulare. This is an example of short-term, asymmetric, apparent competition, in which the presence of one prey species (snails) increases predation on another prey species (the amphipod).

Keywords Columbia River estuary - Predation . Apparent competition · Potamopyrgus antipodarum

\section{Introduction}

Introduced species have been documented to have ecological effects on recipient communities via both direct and indirect interactions. Direct interactions between introduced and native species include predation, competition, and some forms of facilitation. Introduced predators and pathogens often have negative consequences for native species, including extinction (Baxter et al. 2008; Savidge 1987). Introduced competitors are less likely to cause extinction but can change the distribution and abundance of native species (Davis 2003; Sax et al. 2007). Introduced species can also potentially facilitate native species or other introduced species (Bruno et al. 2003; Rodriguez 2006; Schreiber et al. 2002). Indirect interactions involving introduced species, where the effect of one species on another is mediated by a third species, either through changes in density, behavior, or other traits, are less studied but can often have profound effects as well (Noonburg 
et al. 2003; Rowles and O'Dowd 2009; White et al. 2006). This paper addresses both the direct and indirect effects of an introduced prey species on native predators, and reveals indirect effects that have not previously been considered.

In this paper we examine direct and indirect interactions between an introduced consumer, the New Zealand mud snail (Potamopyrgus antipodarum, Gastropoda: Hydrobiidae), native consumers and their shared predators in an estuarine system. Concerns about this nonindigenous species are based primarily on the notion that $P$. antipodarum (1) displace native macroinvertebrates through competition; (2) have low nutritional value for fish: and thus (3) invasion by $P$. antipodarum also has negative effects on native fish predators. This complete chain of events, however, has not been well studied, particularly in estuaries where $P$. antipodarum is now abundant. There is legitimate concern that the introduced $P$. antipodarum represents a low quality prey species that may displace more nutritionally valuable prey items. $P$. antipodarum can become superabundant $\left(>5,00,000\right.$ snails $\left.\mathrm{m}^{-2}\right)$ in highly productive streams (Hall et al. 2006) and it has been shown that rainbow trout grow poorly, if at all, on an exclusive diet of $P$. antipodarum (Vinson and Baker 2008).

Previous research on the food web effects of $P$. antipodarum has focused exclusively on freshwater systems (e.g., Bruce and Moffitt 2005; Vinson and Baker 2008; Woodward et al. 2008). While P. antipodarum is described primarily as a freshwater snail, mud snails are tolerant of salinities up to 15 psu (Alonso and Castro-Diéz 2008) and are found in estuaries throughout their invaded range in Europe (Gerard et al. 2003) and along the west coast of North America (Davidson et al. 2008). This study thus focuses on impacts of $P$. antipodarum in an estuarine food web in brackish Youngs Bay, a shallow embayment in the Columbia River estuary (Oregon). P. antipodarum has been established in Youngs Bay since 1996 where it occurs at high local densities $\left(>2,00,000\right.$ snails $\mathrm{m}^{-2}$ ) (Bersine et al. 2008). These snails have been found in the diet of juvenile Chinook salmon (Oncorhynchus tshawytscha) migrating through the estuary, but little is known about the extent to which $P$. antipodarum have been incorporated into the overall estuarine food web (Bersine et al. 2008).

In regards to direct interactions between native predators and $P$. antipodarum, we expected that feeding mode would affect the consumption and successful digestion of this introduced snail. In addition to native fish, we also included the native signal crayfish (Pacifastacus leniusculus) as a predator in this experiment. In general, we predicted that benthic feeders, such as starry flounder (Platicthys stellatus), would consume more $P$. antipodarum than pelagic feeding predators, such as threespine stickleback (Gasterosteus aculeatus), and that predators that crush their prey, such as signal crayfish, would digest the mud snails more effectively than predators that swallow prey whole. Pilot studies showed that fish such as Pacific staghorn sculpin (Leptocottus armatus) and threespine stickleback, as well as signal crayfish, consume $P$. antipodarum in laboratory and field environments. Our specific hypotheses for the laboratory experiments therefore were that (1) signal crayfish would consume and obtain more energy from snails than would fish, (2) benthic-feeding starry flounder and Pacific staghorn sculpin would consume more snails than pelagic-feeding threespine stickleback, and (3) that fish would not effectively digest $P$. antipodarum while crayfish would crush and digest them. In regards to our field survey, we predicted that $P$. antipodarum would occur primarily in the stomachs of benthic feeding fish.

Introduced prey can exert an indirect effect on native prey and predators by reducing the number of native prey in the diet of shared predators. Mechanisms for this effect could include; (1) direct interference with consumption of native prey, (2) changing predator preferences due to the presence of alternative prey or (3) long-term reductions in native prey availability due to competition. Native benthic invertebrate prey, especially the amphipod Americorophium salmonis, are important in the diet of estuarine fish including juvenile salmonids, flatfish, and sculpin (Bottom and Jones 1990). A. salmonis provides six times more energy per unit biomass than tiny, hard-shelled $P$. antipodarum (Duffy 2003; Sagar and Glova 1995). We predicted that the presence of relatively high densities of $P$. antipodarum would directly interfere with and lower the consumption of native prey species during short-term experiments, potentially resulting in an indirect positive effect on native prey species and an indirect negative effect on the fish via the first mechanism described above. This study does not address the possibility of a reduction in native prey due to direct competition with $P$. antipodarum for resources; however, previous work showed that this snail does not exert strong negative competitive effects on the native isopods (Gnorimosphaeroma insulare) or amphipods (A. salmonis), although they do overlap in habitat (benthos) and resource use (algae, detritus) (Brenneis et al. 2010).

In order to measure direct and indirect interactions between $P$. antipodarum, native invertebrate prey and their predators we used a combination of laboratory experiments and a field study of fish diets. Our first experiment compared consumption rates of predators with different feeding modes on $P$. antipodarum, and on native benthic invertebrate prey in both the presence and absence of mud snails. This experiment addressed the following questions: (1) Do common native estuarine predators consume $P$. antipodarum? (2) Do these predators differ in their consumption of P. antipodarum? and (3) Does the presence of $P$. antipodarum affect consumption of common native 
invertebrate prey species (the isopod, $G$. insulare and the amphipod, A. salmonis) and thus the energetic content of predator diets? We performed a second experiment to clarify two questions about fish predation on $P$. antipodarum: (1) When only $P$. antipodarum are available, are they consumed? and (2) When P. antipodarum are consumed by predators, are they digested or do they survive gut passage alive or intact? As a complement to the laboratory studies, we performed stable isotope $\left({ }^{13} \mathrm{C} /{ }^{15} \mathrm{~N}\right)$ and gut content analyses on field-caught fish to characterize food web structure and determine the extent to which $P$. antipodarum were incorporated into the diet of common estuarine fish in the wild.

\section{Methods}

General experimental set up

During July 2008, we collected prey and predator species in Youngs Bay, Oregon, from intertidal rocks and mud (prey species), by seining (fish species), and with crayfish traps. Animals were maintained for 1 month at the Astoria High School Applied Science Center wet lab in aerated $37.9 \mathrm{~L}$ holding tanks filled with $15^{\circ} \mathrm{C}$ spring water brought to a salinity of 5 psu with the addition of InstantOcean. Fish and crayfish were fed brine shrimp daily and readily consumed this food. Invertebrates were provided with periphyton-covered tiles, which allowed ad libitum feeding. Experimental tanks $\left(37.9 \mathrm{~L}, 4.1-5.2 \mathrm{psu}, 15-16^{\circ} \mathrm{C}\right)$ were aerated with a diffuser. An $\sim 1 \mathrm{~cm}$ deep layer of sand (Aragonite) served as substrate and as a refuge for the tubebuilding amphipods (A. salmonis) that encased themselves in sand during the experiment. Two unglazed ceramic tiles (24 $\mathrm{cm}^{2}$ each) colonized with algae were placed on top of the sand in each tank to provide a food source for prey during the experiment. Prior to use in the experiment, individual predators were held in separate tanks for a set period of time ( $24 \mathrm{~h}$, Experiment 1 or $48 \mathrm{~h}$, Experiment 2) to ensure uniform hunger levels.

\section{Experiment one-multiple prey species available}

The first experiment had a $5 \times 2$ factorial design with five predator treatments (four predator species and a predatorfree control) and two prey treatments (native prey only (both amphipods and isopods) versus a mix of these two native prey species along with $P$. antipodarum; Table 1). The predators included Pacific staghorn sculpin (70-80 $\mathrm{mm}$ total length), threespine stickleback (50-60 mm), juvenile starry flounder $(65-125 \mathrm{~mm})$, and signal crayfish $(70-75 \mathrm{~mm}$ carapace length). These ten treatments were repeated over time for a total of five replicate blocks. Prey survival was
Table 1 Treatments for experiment one

\begin{tabular}{ll}
\hline Treatment & Species combination \\
\hline 1 & $10 G+10 A+50 P+$ no predator \\
2 & $10 G+10 A+50 P+$ PSS (Pacific staghorn sculpin) \\
3 & $10 G+10 A+50 P+$ SF (starry flounder) \\
4 & $10 G+10 A+50 P+$ TSS (threespine stickleback) \\
5 & $10 G+10 A+50 P+$ crayfish (signal crayfish) \\
6 & $10 G+10 A+$ no predator \\
7 & $10 G+10 A+$ PSS (Pacific staghorn sculpin) \\
8 & $10 G+10 A+$ SF (starry flounder) \\
9 & $10 G+10 A+$ TSS (threespine stickleback) \\
10 & $10 G+10 A+$ crayfish (signal crayfish) \\
\hline
\end{tabular}

$G$ indicates the native isopod Gnorimosphaeroma insulare, $A$ indicates the native amphipod Americorophium salmonis, and $P$ indicates the invasive New Zealand mud snail Potamopyrgus antipodarum. Numbers indicate the number of individuals added to each tank. One individual of each predator species was added. Each treatment was replicated five times

compared between predator species and between treatments with and without $P$. antipodarum. The experimental numbers of each prey species reflected the relative densities of these species in the interidal environment (Brenneis et al. 2010): either $10 G$ (G. insulare) $+10 A$ (A. salmonis) or $10 G+10 A+50 P(P$. antipodarum $)$ were added to the experimental tanks along with algal tiles $2 \mathrm{~h}$ prior to the addition of predator species. We opted to add the introduced species $(50 P)$ without reducing the number of native prey $(10 G+10 A)$, which results in an overall increase in prey availability because this scenario most closely reflects the field patterns observed in this system (Brenneis et al. 2010).

After a 24-h starvation period, one predator (or none in the case of the control) was added to each tank and allowed to feed for $13 \mathrm{~h}$ (from 17:00 to 6:00) on a natural lightdark cycle (dark from 20:00 to 5:00). Each individual predator was used only once during the course of the experiment. After $13 \mathrm{~h}$, which allowed feeding at dusk and dawn, predators were removed, rinsed (to remove sand or snails), and placed in recovery tanks. We removed the contents of the experimental tanks and counted all remaining prey. Recovery rates of the three prey species were high in the no predator control treatment (98-100\%) and did not differ significantly from each other (ANOVA, $F_{2,22}=1.65, P=0.21$ ). Predators were kept in recovery tanks for $57 \mathrm{~h}$, a time period sufficient to allow gut clearance. A $5 \mathrm{~mm}$ mesh screen fixed approximately $2 \mathrm{~cm}$ off the bottom of the tank allowed egested material (feces, shells) to fall through and prevent re-consumption by predators. After $57 \mathrm{~h}$, we removed recovery tank contents and noted the condition of egested snails (alive, dead but intact, or shell fragments). 
Parameters analyzed

We used three different parameters to describe the results of the first experiment. The first, prey consumption, was expressed either as the number consumed or as a percentage (calculated simply as the number of individuals at the start of the experiment minus the number of individuals present at the end of the experiment divided by the starting number). The second, the amount of energy consumed by predators, was calculated by multiplying the number of prey consumed in the treatment by the average mass of an individual prey item ( $P$ and $A, 0.006 \mathrm{~g}, G, 0.007 \mathrm{~g}$ ) to obtain total grams wet weight consumed. This was multiplied by estimates of prey energy density from the literature ( $\mathrm{J} \mathrm{g}^{-1}$ wet weight). Values used in these calculations were $P=675 \mathrm{~J} \mathrm{~g}^{-1}, A=4,408 \mathrm{~J} \mathrm{~g}^{-1}$, and $G=3,391 \mathrm{~J} \mathrm{~g}^{-1}$ (Duffy 2003; Sagar and Glova 1995).

The third parameter we calculated was Chesson's alpha $(\alpha)$ which provides a measure of prey preference for each of the predator species (Chesson 1983).

$\alpha_{i}=\frac{r_{i} / n_{i}}{\sum_{j=1}^{m} r_{j} / n_{j}}$

where $r_{i}$ is the number of individuals of prey species $i$ consumed and $n_{i}$ is the number of individuals of species $i$ available for all prey species available $(j)$. For $P, n$ was 50 and for $A$ and $G, n$ was 10 . In both cases, $n$ was held constant because resources were not depleted to low levels during the course of the experiment. We calculated Chesson's alpha in treatments with $P$. antipodarum to determine which of the three prey species was preferred by each predator. We also calculated Chesson's alpha for native species only by excluding predation on $P$. antipodarum from the calculations in order to compare changes in relative preference for amphipods (A. salmonis) or isopods (G. insulare) in treatments with versus without $P$. antipodarum.

\section{Experiment two-Potamopyrgus antipodarum as the only prey available}

The second experiment was designed to increase the likelihood of $P$. antipodarum consumption in order to observe the condition of $P$. antipodarum that were egested by fish. Because the first experiment established that crayfish successfully consume and digest $P$. antipodarum, only fish predators (sculpin, stickleback and starry flounder) were used in the second experiment. In experiment two, fish were starved for $48 \mathrm{~h}$ (as opposed to $24 \mathrm{~h}$ ) prior to use. One fish was placed in a tank and allowed to feed on 50 P. antipodarum for $22 \mathrm{~h}$ (17:00-15:00 the following day).
Fish were then rinsed and transferred to a recovery tank as described in experiment one. Egested materials were removed after $44 \mathrm{~h}$ (sufficient for gut clearance). In this experiment we determined the number of $P$. antipodarum consumed as well as the fate of the snails that were consumed. The fate of the snails after egestion was noted as alive, intact (minimal shell damage), or digested (shell fragments only).

\section{Field survey methods}

Field surveys were conducted in two bays at the mouth of the Columbia River Estuary, Oregon-Washington. We selected these two bays in order to compare the frequency of $P$. antipodarum in the diet of fish in a highly invaded bay versus a bay where these snails had not yet established high densities. Youngs Bay (YB) has a history of $P$. antipodarum invasion (documented since 1996) and these snails now occur at medium to high densities throughout the bay (up to 2,00,000 snails $\mathrm{m}^{-2}$ ). In contrast, $P$. antipodarum is absent or present at very low densities at sites in Baker Bay (BB). Fish samples were collected every 3 weeks during the summer of 2008 (July 21-22, August 13-14, September 2-3) at two sites in each bay. Sites were sampled during the daytime low tide with a beach seine net $(38.1 \mathrm{~m} \times 3 \mathrm{~m}$ with $0.64 \mathrm{~cm}$ mesh wings and $0.48 \mathrm{~cm}$ mesh center) deployed in a circular pattern from a boat and pulled up on shore (water depth 1-3 m). This sampling method captures both benthic and shallow-water pelagic fish. Target fish included Pacific staghorn sculpin, shiner perch (Cymatogaster aggregata), threespine stickleback, starry flounder, and English sole (Pleuronectes vetulus).

We collected data on salinity, temperature, fish count, and lengths of the first 30 fish of each species removed from the net. Three Petite Ponar grab samples were collected from sand substrate at a depth of $\sim 1 \mathrm{~m}$ to quantify benthic macroinvertebrate density. Contents of the grab samples were rinsed through a $500 \mu \mathrm{m}$ mesh sieve, preserved in $70 \%$ ethanol and then counted. Ten fish of each species per site were euthanized with MS-222 (tricaine methane sulphonate) and kept in a freezer at $-20^{\circ} \mathrm{C}$ until analysis. In the laboratory each fish was measured and weighed prior to removal of the stomach and intestines that were then preserved in buffered $10 \%$ formalin. Stomachs were rinsed and weighed and the percentage full was estimated based on volume. Prey taxa were identified to the lowest taxonomic level possible, counted, and weighed (after $10 \mathrm{~min}$ of airdrying) to calculate frequency of occurrence, weight percentage, and numerical percentage of each prey type. Intestinal contents were inspected for presence of $P$. antipodarum and when encountered, the degree of digestion was noted (intact shell or shell fragments). 
Fish stomach contents were used to calculate the index of relative importance (IRI) for each fish species (Pinkas et al. 1971). This index was used because it reflects the contributions of both large numbers of very small prey and low numbers of big prey, and how common these prey items are in the diet compared to other prey items. Parameters include the percentage of prey species by number $(N)$, biomass $(M)$ and frequency of occurrence $(P)$ in the diet

$$
\mathrm{IRI}=(N+M) P .
$$

We calculated a single IRI for each prey species in each bay (two sites combined) for the summer hydrologic season (July-September). This gives a value that expresses how important a given prey item is in the diet of a particular fish. To compare stomach contents for different fish species, each prey IRI value was expressed as a percentage of the total of all prey values calculated for each predator species:

Total IRI $\%=\frac{\sum_{j=1}^{n} \operatorname{IRI}_{i j}}{\sum_{j=1}^{n} \sum_{i=1}^{m} \operatorname{IRI}_{i j}} \times 100$

where $\mathrm{IRI}_{i j}=$ Index of relative importance for prey taxon $i$ in fish category $j, n=$ total number of fish sampled of a single taxon, year class, and bay, $m=$ total number of all prey taxa.

Finally, the stable isotope $\left({ }^{13} \mathrm{C} /{ }^{15} \mathrm{~N}\right)$ ratios of tissue samples from fish (muscle) and invertebrates (entire organism, snail shells removed) were analyzed. The stable isotope ratio of crayfish, which live in the tributaries of the bay, rather than the open beaches sampled during this field survey, were not analyzed. While stable isotope ratios cannot be used to directly assess the contribution of $P$. antipodarum to the diets of fish predators, this information does provide more general information about food web structure. Carbon isotope ratios can provide information about the nature of primary producers at the base of the food web. For example, benthic signatures (periphyton) are enriched (more of the heavier isotope ${ }^{13} \mathrm{C}$ ) compared to pelagic signatures (phytoplankton). Nitrogen ratios give an indication of trophic level; $\delta^{15} \mathrm{~N}$ values are more enriched at higher trophic levels (Jardine et al. 2003; Post 2002; Vander Zanden et al. 1997). Tissue was dried at $60^{\circ} \mathrm{C}$ for $48 \mathrm{~h}$ and ground to a powder. $1 \mathrm{mg}$ of tissue was weighed into tin capsules that were then analyzed by the Stable Isotope Facility at the University of California, Davis using a PDZ Europa ANCA-GSL elemental analyzer interfaced to a PDZ Europa 20-20 isotope ratio mass spectrometer (Sercon Ltd., Cheshire, UK). We used the ISOERROR mixing model to estimate the proportion of consumer diets derived from plankton $(>80 \mu \mathrm{m})$ versus periphyton using $\delta^{13} \mathrm{C}$ values (Phillips and Gregg 2001). We estimated $\delta^{13} \mathrm{C}$ fractionation between trophic levels as $0.4 \%$. Based on $\delta^{15} \mathrm{~N}$ values, we assigned a trophic level of 2 to invertebrates and 3 to fish; information on trophic levels is needed so that the appropriate fractionation values can be incorporated into the mixing model. Stable isotope ratios for plankton $(n=16)$ and periphyton $(n=8)$ were based on samples collected from Youngs Bay using plankton tows and rock scrapings.

Statistical analysis

A one-way analysis of variance (ANOVA) was used to test for differences in the number of $P$. antipodarum consumed by different predators. A two-way ANOVA, with predator species identity and $P$. antipodarum presence/absence as factors, was used to compare differences in consumption of native invertebrates between treatments. Block was initially included as a factor but was found to be non-significant in all cases and was subsequently dropped from the analysis ( $F$ always $<0.9, P$ always $>0.5$ ), allowing tests for interactions between predator type and $P$. antipodarum presence. Energetic content of prey consumed in different treatments were compared using $t$ tests [energy consumed in $P$. antipodarum absent versus present (native prey only), and total energy consumed in treatments with $P$. antipodarum absent vs. present]. Planned contrasts were used to test for differences between number of prey and energy $(\mathrm{J})$ consumed in same-predator treatments with and without $P$. antipodarum. For isopod ( $G$. insulare) consumption, variance was not homogenous even after $\log (X+1)$ transformation, so we used the non-parametric Mann-Whitney $U$ test to evaluate differences in $G$. insulare consumption by each predator based on $P$. antipodarum presence.

For preference, we used a multivariate analysis of variance (MANOVA) to test for differences between predators in overall preference for the three prey types because values for Chesson's alpha for each prey species were not independent. The MANOVA showed a significant effect of predator on preference and were followed up with individual ANOVAs. To evaluate effects of the presence versus the absence of $P$. antipodarum on a given predator's preference for A. salmonis, we used the Mann-Whitney $U$ test. For Mann-Whitney $U$ tests, we determined the two-tailed significance using small-sample tables $\left(n_{1}=\right.$ $n_{2}=5$ ). Analyses were performed with JMP-IN software v.5.1.2 ${ }^{\odot}$ SAS Institute.

\section{Results}

Experiment one-multiple prey species

Predators of all species consumed P. antipodarum to some degree; however, consumption was significantly higher in 
the crayfish treatment than in fish predator treatments (Table 2; ANOVA, $F_{3,16}=89.04, P<0.0001$ ). When $P$. antipodarum was present, signal crayfish and Pacific staghorn sculpin (PSS) consumed more A. salmonis than in treatments where $P$. antipodarum was absent (Fig. 1a). Pre-planned contrasts showed that both crayfish and sculpin consumed significantly more A. salmonis when snails were present $(n=5, t=-2.40, P=0.02 ; n=5, t=$ $-2.11, P=0.04$, respectively). There was no significant effect of $P$. antipodarum presence on the number of G. insulare consumed (Fig. 1b, Mann-Whitney $U$ tests, $n_{1}=n_{2}=5: \quad \mathrm{CF}, \quad U=7, \quad P=0.238 ; \quad$ PSS,$\quad U=5$, $P=0.143 ; \quad \mathrm{SF}, \quad U=12.5, \quad P=1 ; \quad \mathrm{TSS}, \quad U=5.5$, $P=0.167)$.

The amount of energy provided to fish by the ingestion of native prey did not differ between treatments with and without $P$. antipodarum. There was, however, a significant positive effect of $P$. antipodarum presence for signal crayfish. For crayfish, both the energy from native prey (ANOVA, $F=32.15, P=0.09$ ) and the total energy of prey consumed (including $P$. antipodarum) (ANOVA, $F=4.7, P=0.0006$ ) were higher in treatments with $P$. antipodarum than those without (Fig. 2).

In the presence of $P$. antipodarum, prey preference differed between predators (Fig. 3; MANOVA, Predator, Wilks $\quad \lambda=0.12, \quad$ approximate $F_{9,34.2}=5.14, \quad P=$ $0.0002)$. The fish showed a significantly stronger preference for $A$. salmonis than did crayfish (ANOVA, $\left.F_{1,18}=15.15, P=0.0011\right)$. In contrast, crayfish (CF) showed a stronger preference for $P$. antipodarum than did the fish (ANOVA, $F_{1,18}=97.2, P<0.0001$ ). Preference differed in some respects from the number of prey consumed. Paired contrasts between treatments with and without $P$. antipodarum showed that preference for A. salmonis increased in the presence of $P$. antipodarum for Pacific staghorn sculpin (Mann-Whitney $U$ test, $\left.n_{1}=n_{2}=5, U=1, P=0.016\right)$ and threespine stickleback $\left(n_{1}=n_{2}=5, U=0, P=0.016\right)$, with corresponding decreases in preference for $G$. insulare (Fig. 4). This change in preferences was due to an increase in A. salmonis consumption and a decrease (though non-significant) in

Table 2 Number of $P$. antipodarum consumed by predators in experiment one $(n=5)$

\begin{tabular}{lcccc}
\hline Predator & Minimum & Median & Mean & Maximum \\
\hline Crayfish & 24 & 36 & 35.8 & 45 \\
PSS & 0 & 3 & 3 & 4 \\
SF & 0 & 0 & 0.4 & 0 \\
TSS & 0 & 0 & 1.2 & 2 \\
\hline
\end{tabular}

crayfish signal crayfish, PSS Pacific staghorn sculpin, SF starry flounder TSS threespine stickleback

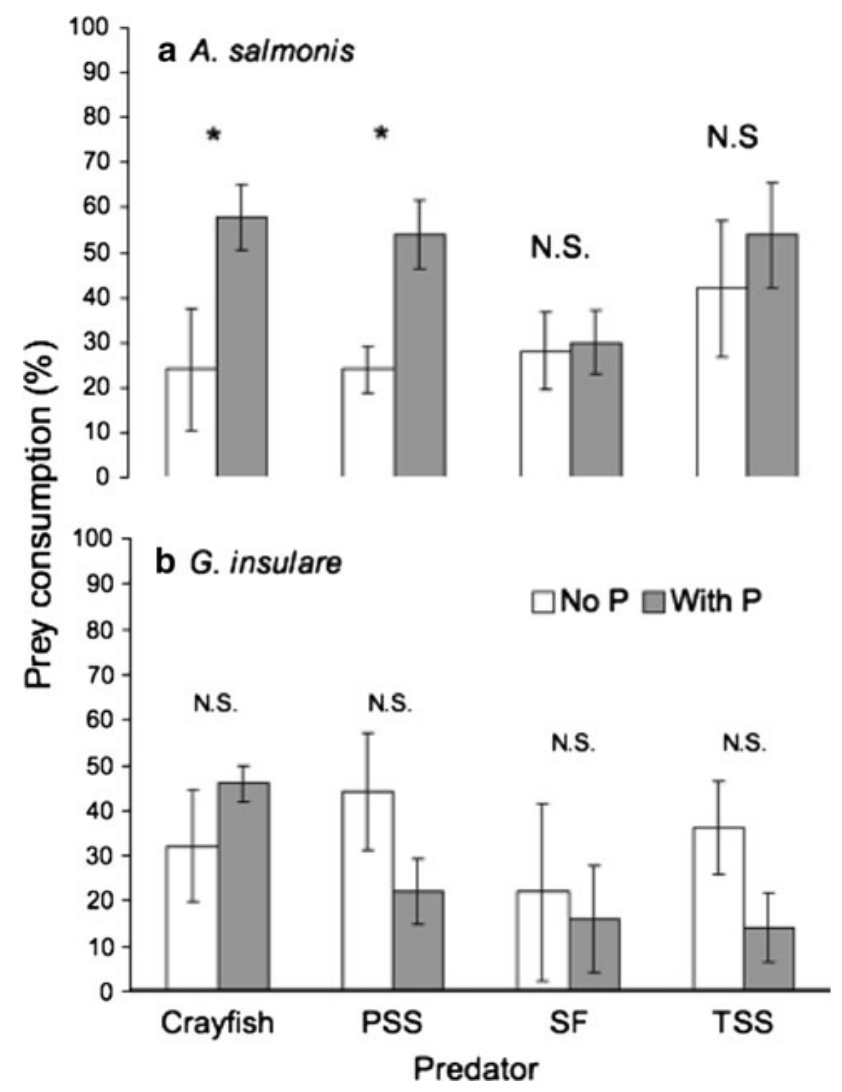

Fig. 1 Consumption of a native amphipods (A. salmonis) and b native isopods $(G$. insulare) by four predators in treatments with (shaded bars) and without (open bars) the invasive New Zealand mud snail $P$. antipodarum $(P)$, mean $\pm 1 \mathrm{SE}, n=5$. Four predator treatments were crayfish, Pacific staghorn sculpin (PSS), starry flounder (SF), and threespine stickleback (TSS). Asterisks indicate significant differences when $P$. antipodarum were present (a crayfish, $t=-2.40, p=0.02$ and sculpin; PSS, $t=-2.11, p=0.04)$. NS no significant effect of $P$. antipodarum presence at $\alpha=0.05$. Experiment performed during July 2008 in Astoria, Oregon, USA

$G$. insulare consumption in the presence of $P$. antipodarum. Preference did not change significantly for crayfish $\left(n_{1}=n_{2}=5, \quad U=5, \quad P=0.270\right)$ or starry flounder $\left(n_{1}=n_{2}=5, U=9.5, P=1\right)$.

Experiment two-Potamopyrgus antipodarum as only prey available

When $P$. antipodarum were the only prey available, they were consumed by all three fish species in low numbers. Individual Pacific staghorn sculpin consumed between 0 and 3 snails each, juvenile starry flounder consumed between 0 and 11 snails, and threespine stickleback consume between 0 and 11 snails. At least one individual fish of each species consumed $P$. antipodarum and many of the snails consumed by each fish predator species were not digested (Fig. 5 shows combined results from experiment one and two). Individual snails survived gut passage alive 


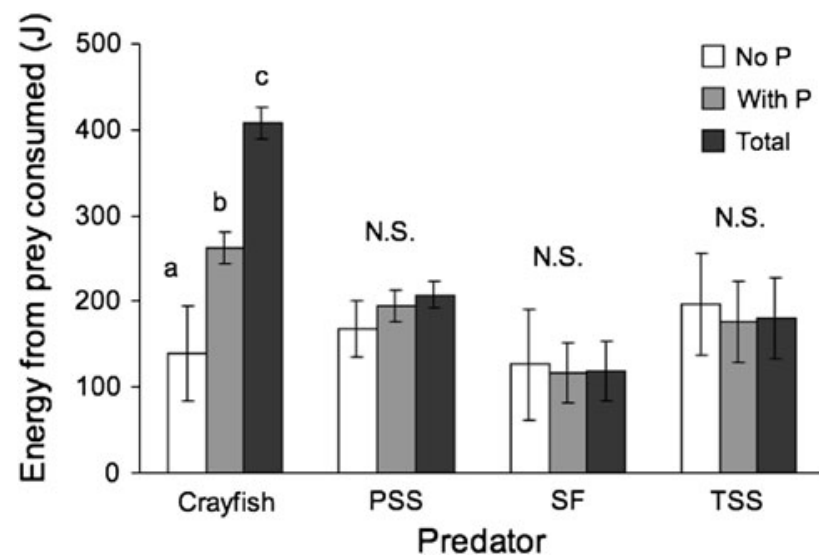

Fig. 2 Joules of energy provided by native prey consumed by four predators in treatments with (shaded bars) and without (open bars) $P$. antipodarum $(P)$ and total energy (black bars) including $P$. antipodarum. Letters indicate significant differences of energy intake for crayfish with $P$. antipodarum $(F=32.15, p=0.09)$ and for total energy $(F=4.7, p=0.0006)$

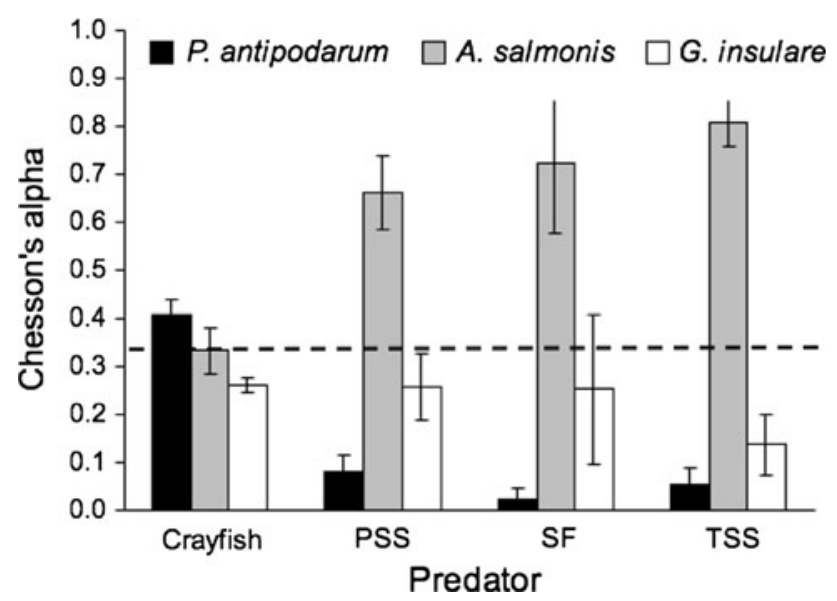

Fig. 3 Predator preference (Chesson's $\alpha$ ) for three invertebrate prey species: P. antipodarum $(P), A$. salmonis $(A)$, and $G$. insulare $(G)$, mean $\pm 1 \mathrm{SE}, n=5$. Crayfish showed a preference for $P$. antipodarum (ANOVA, $F_{1,18}=97.2, P<0.0001$ ) while Pacific staghorn sculpin (PSS), starry flounder (SF), and threespine stickleback (TSS) fish showed a preference for A. salmonis (ANOVA, $F_{1,18}=15.15$, $P=0.0011)$. Dashed line indicates no preference $(\alpha=0.33$ for each of three species)

in at least one individual of each of the three fish species. In contrast, all snails consumed by crayfish were digested.

Field survey

$P$. antipodarum were found at low numbers in the stomach and intestines of wild caught adult shiner perch, juvenile English sole, and Pacific staghorn sculpin (Table 3). Fish catch varied between bays; English sole and starry flounder were caught almost exclusively in Baker Bay, while threespine stickleback and shiner perch were much more abundant in Youngs Bay (ESM Appendix A). P. antipodarum

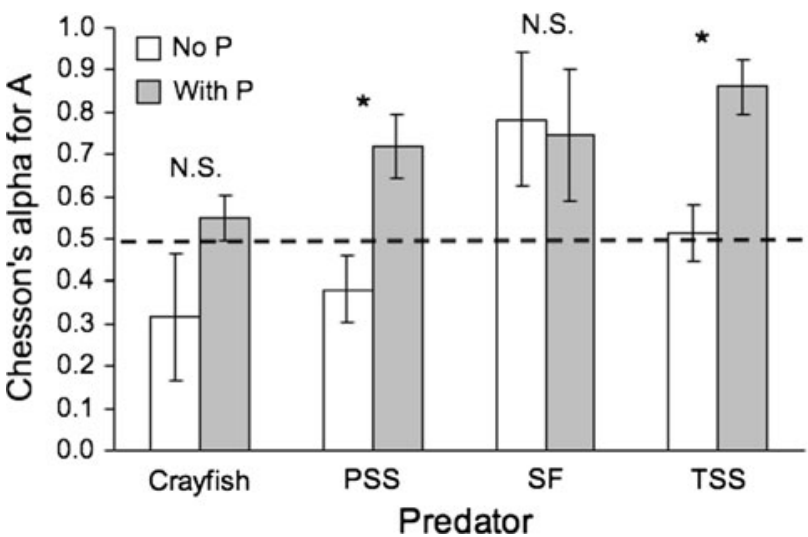

Fig. 4 Relative preference by four predators for A. salmonis $(A)$ over G. insulare $(G)$ in treatments with (shaded bars) and without (open bars) $P$. antipodarum $(P)$. Asterisk indicates significant preference for A. salmonis by PSS and TSS based on Mann-Whitney $U$ test, $n_{1}=n_{2}=5$. NS indicates no significant difference. Dashed line represents no preference $(\alpha=0.50)$

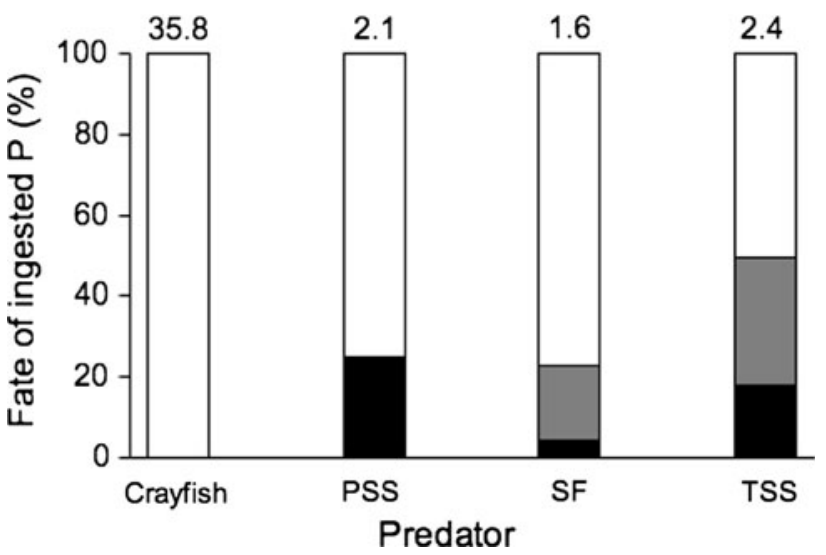

Fig. 5 Fate of $P$. antipodarum $(P)$ consumed by four predators shown as the percentage of the total number consumed during experiment one and two (mean number of snails consumed are shown above each bar). 'Alive' (black fill) means that $P$. antipodarum survived gut passage, 'intact' (shaded fill) means that the snail was dead but undigested, and 'digested' (white fill) means that only shell fragments were present in the recovery tank. Predator abbreviations are the same as in previous figures

densities were much higher in Youngs Bay than in Baker Bay (ESM Appendix A).

The index of relative importance (IRI) for $P$. antipodarum was highest for adult shiner perch caught in Youngs Bay (32\% of total IRI), due primarily to the presence of many (20) snails in the stomach of one fish (Fig. 6 and ESM Appendix B). Generally, amphipods in the genus Americorophium were important in the diet of shiner perch, young of the year English sole and starry flounder, threespine stickleback and Pacific staghorn sculpin. Nereid polycheates were important in the diet of adult shiner perch in Baker Bay, as well as juvenile English sole, starry flounder, threespine stickleback and Pacific staghorn 

caught fish with $P$. antipodarum $(P)$ in stomach or intestines and P. antipodarum load per fish
Table 3 Proportion of wild-

\begin{tabular}{llll}
\hline & $\begin{array}{l}\text { No. of fish with } \\
P \text { (total \# of fish) }\end{array}$ & $\begin{array}{l}\% \text { of fish } \\
\text { with } P\end{array}$ & $\begin{array}{l}\text { No. of } P \\
\text { per fish }\end{array}$ \\
\hline Youngs Bay & & & 1 \\
Pacific staghorn sculpin (PSS) & $1(10)$ & 10 & 0 \\
Threespine stickleback (TSS) & $0(60)$ & 0 & 2,20 \\
Shiner perch (SP) & $2(49)$ & 4.1 & 0 \\
Starry flounder (SF) & $0(1)$ & 0 & - \\
English sole (ES) & - & - & 0 \\
Baker Bay & $0(10)$ & 0 & 0 \\
Pacific staghorn sculpin (PSS) & $0(11)$ & 0 & 0 \\
Threespine stickleback (TSS) & $0(35)$ & 0 & 0 \\
Shiner perch (SP) & $0(31)$ & 0 & 1,1 \\
Starry flounder (SF) & $2(57)$ & 3.5 & \\
English sole (ES) & & & \\
\hline
\end{tabular}

sculpin from Baker Bay. Copepods were present in the diets of shiner perch and threespine stickleback. There was relatively little overlap in the fish species taken from the two bays (apart from shiner perch and stickleback) and because the total number of fish with $P$. antipodarum was so low, we did not address the 'effect' of $P$. antipodarum density on the diets of these fish.

Stable isotope values for fish predators and invertebrates sampled in Youngs and Baker Bays are shown in Fig. 7. $\delta^{13} \mathrm{C}$ and $\delta^{15} \mathrm{~N}$ values were averaged across bays for invertebrates and basal resources (periphyton and phytoplankton) and separated by bay for fish species in order to detect potential differences between bays. $\delta^{13} \mathrm{C}$ values for plankton ranged between -27 and $-26 \%$ and for periphyton the values ranged between -17 and $-15 \%$, providing a characteristic differentiation between pelagic and benthic basal resources in the diet of estuarine consumers. Results of the ISOERROR mixing model showed that $P$. antipodarum and the isopod $G$. insulare fed primarily on periphyton $(73 \pm 0.08$ and $72 \pm 0.2 \%$ of the diet, respectively), while the amphipod $A$. salmonis and Nereid worms fed primarily on phytoplankton-based resources (72 \pm 0.08 and $81 \pm 0.07 \%$, respectively; ESM Appendix C). Threespine stickleback fed primarily on a planktonbased food web, while other fish consumed a mixture of benthic and pelagic feeding prey.

\section{Discussion}

Estuarine predators interact directly with the introduced New Zealand mud snail (Potamopyrgus antipodarum) to varying degrees through the consumption of this small aquatic snail. As predicted, signal crayfish, which are native in the tributaries of this system, consume significantly more $P$. antipodarum than do fish predators and they

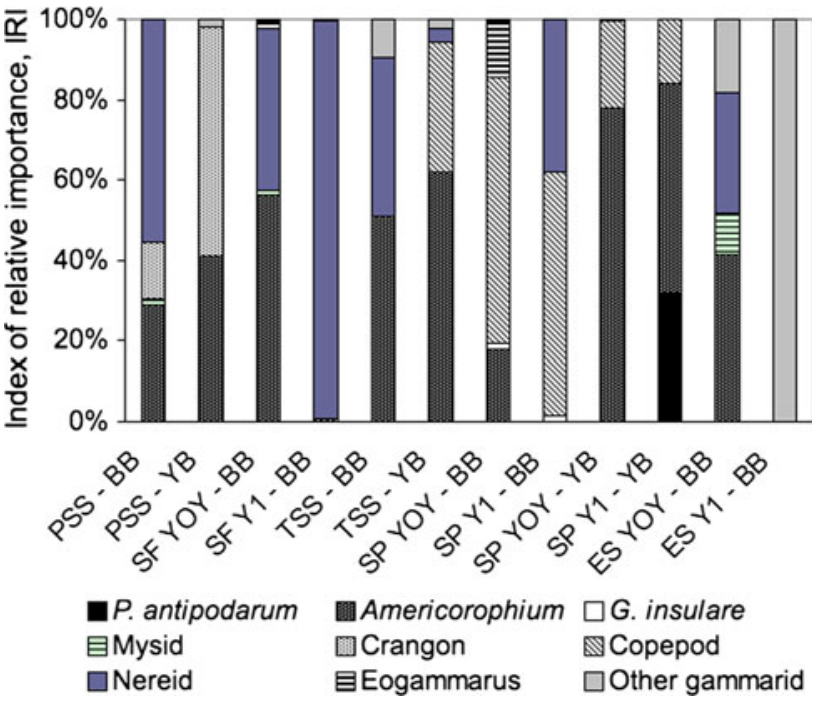

Fig. 6 Index of relative importance (IRI) of prey consumed by fish caught during summer 2008 field survey based on the composition of prey in the stomach only. Fish include Pacific staghorn sculpin (PSS), starry flounder $(S F)$, threespine stickleback $(T S S)$, shiner perch $(S P)$, and English sole $(E S)$. When distinct, separate year classes are displayed as young of the year $(Y O Y)$ or year one $(Y 1)$. Values are averaged for each bay: Youngs Bay $(Y B)$ and Baker Bay $(B B)$

receive significant energetic benefits from this non-native snail. P. antipodarum are consumed in low numbers by threespine stickleback, juvenile starry flounder, and Pacific staghorn sculpin in laboratory experiments, and contrary to our predictions, the number of snails consumed does not differ between fish based on feeding mode. While crayfish digest mud snails effectively as predicted, a proportion of snails $(20-50 \%)$ consumed by fish survived gut passage intact or alive, indicating that fish derive little energetic benefit while serving as a potential transport vector for mud snails (Bruce and Moffitt 2005; Vinson and Baker 2008). 


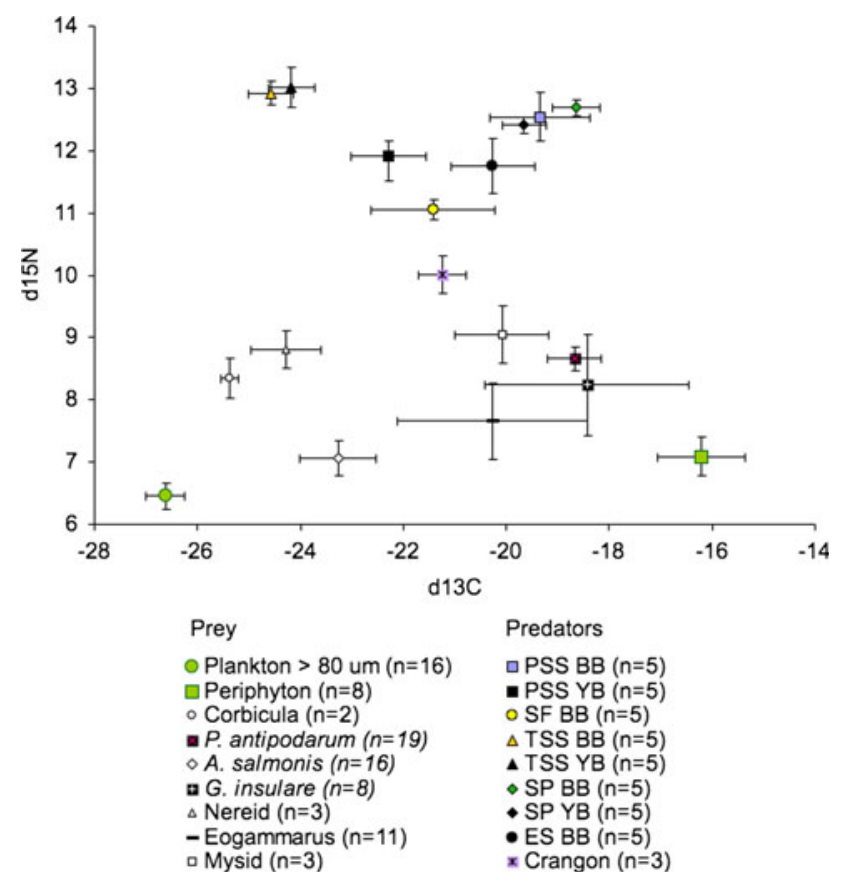

Fig. 7 Stable isotope bi-plot of $\delta^{13} \mathrm{C}$ and $\delta^{15} \mathrm{~N}$ for fish and common prey items in Youngs Bay $(Y B)$ and Baker Bay $(B B)$, mean \pm SE. Fish include Pacific staghorn sculpin $(P S S)$, starry flounder $(S F)$, threespine stickleback (TSS), shiner perch $(S P)$, and English sole $(E S)$

$P$. antipodarum are not an important component of the diet for the studied estuarine fish. Previous studies have shown that $P$. antipodarum, even when completely digested, have relatively low energetic value compared to amphipods and larger snails (Hanson 1997; McCarter 1986). The results of field diet surveys corroborate the lab results as they demonstrate that $P$. antipodarum are found at only low numbers in the stomach and intestines of wild caught fish and the index of relative importance (IRI) for $P$. antipodarum in the diets of fish is generally very low. Taken as a whole, these results indicate that while estuarine fish consume $P$. antipodarum, the snails do not constitute a significant portion of the diet, and therefore the direct interactions between this introduced snail and native fish are minimal.

The indirect effects of $P$. antipodarum on native invertebrates and predators tell a more interesting story. While $P$. antipodarum are not consumed in large numbers (except by crayfish predators), the presence of $P$. antipodarum alters predation on native prey, but not in the expected direction. $P$. antipodarum presence does not significantly change the number of isopods ( $G$. insulare) consumed, but interestingly, the presence of snails increased the number of the amphipods (A. salmonis) consumed by crayfish and sculpin, rather than causing the predicted decrease in consumption of native prey. Predator preference for amphipods and isopods also shifts in the presence of
$P$. antipodarum; preference for amphipods increases for both threespine stickleback and Pacific staghorn sculpin, with corresponding decreases in preference for isopods. Overall, the fact that the presence of large numbers of $P$. antipodarum either has no effect or increases the quantity of common native invertebrate prey or total energetic value consumed by predators, is in direct opposition to the common concern that $P$. antipodarum have a negative effect on fish by substantially reducing consumption of nutritious native prey species in this system (Bersine et al. 2008; Vinson and Baker 2008). P. antipodarum may, however, have an indirect negative effect on the native amphipod, A. salmonis, through an increase in consumption by shared predators.

Increased predation on one prey species due to the presence of another can be described as apparent competition (Holt 1977); although this case is better described as short-term apparent competition (Holt and Kotler 1987) as the time scale of the experiment is too short to observe an increase in predator populations (a mechanism of apparent competition). Here, we have evidence for asymmetric apparent competition, in which the presence of the snail $P$. antipodarum somehow triggers an increase in predation on, or preference for, the cryptic, tube-building amphipod A. salmonis by several predator species. The presence of an obvious prey item, such as $P$. antipodarum here, has been shown to increase predation on cryptic prey in other aquatic systems (Zhang and Richardson 2007).

The mechanism for this short-term apparent competition is most likely a change in predator behavior. The presence of snails may have provided a visual or chemical cue that induced greater foraging effort among predators. In the case of signal crayfish, amphipod consumption increased in the presence of snails, likely due to increased encounters as crayfish processed the sand substrate through their chelipeds. Pacific staghorn sculpin also consumed more amphipods in the presence of snails. Similarly, threespine stickleback preference for amphipods increased greatly in the presence of snails due to a combination of increased amphipod consumption and decreased (although non-significant) isopod consumption. Further studies are needed to determine whether the presence of snails increases benthic foraging by fish and crayfish. These results indicate that it is important to consider not only the direct effects of introduced species, but also the predator-mediated effects of invasion by novel prey on native prey. In general, based on the results of this study, we predict that these predatormediated effects will be stronger in systems where novel, low-value prey become abundant and induce a change in predator behavior.

Stable isotope analysis, which provides information on the relative importance of benthic versus pelagic resources in the diet of invertebrates and fish, cannot provide specific 
information on the importance of $P$. antipodarum in the diet of fish. What we can see, using the combination of gut content analysis and stable isotope data, is that benthic feeding fish (e.g., English sole) are more likely than pelagic fish (e.g., threespine stickleback) to have snails in their diet. Whether this is due to accidental ingestion or active selection is unknown; however, it is interesting to note that snails were found in the diet of juvenile English sole taken from Baker Bay where snail densities are extremely low. It may be that juvenile English sole have not yet learned to avoid $P$. antipodarum due to lack of experience. Threespine stickleback, which did ingest $P$. antipodarum in a laboratory environment, generally feed more on pelagic resources and wild fish did not have any snails in their diets.

Overall, our findings for this estuarine system do not support the conventional wisdom that $P$. antipodarum replace native prey in the diets of fish. Contrary to the frequently stated management concern, fish did not eat less native prey when $P$. antipodarum was present; in fact some predators increased their consumption of native species. While it is tempting to make generalizations about the impacts of introduced species on recipient communities, this study illustrates that these effects are often subtle and depend on species and community context.

Acknowledgments This research was supported by a Henry A. Jastro and Peter J. Shields Graduate Research Scholarship Award from UC Davis. V.B. was supported by a National Science Foundation graduate research fellowship. Facilities and equipment were provided by the Astoria High School Applied Science Center. We thank the Columbia River Estuary Study Taskforce for the use of their boat, gear and pilots. J.Z. and K.B. of the NOAA Pt. Adams lab provided guidance on gut content analysis. We thank R.L., L.L., D.B., W.F., L.C., A.L., B.S., L.B.-K., J.H., K.A., L.B., M.S., J.H. and M.S. for support with the field and lab components of this work.

Open Access This article is distributed under the terms of the Creative Commons Attribution Noncommercial License which permits any noncommercial use, distribution, and reproduction in any medium, provided the original author(s) and source are credited.

\section{References}

Alonso A, Castro-Diéz P (2008) What explains the invading success of the aquatic mud snail Potamopyrgus antipodarum (Hydrobiidae, Mollusca)? Hydrobiologia 614:107-116

Baxter PWJ, Sabo JL, Wilcox C, McCarthy MA, Possingham HP (2008) Cost-effective suppression and eradication of invasive predators. Conserv Biol 22:89-98

Bersine K, Brenneis VEF, Draheim RC, Wargo Rub AM, Zamon JE, Litton RK, Hinton SA, Sytsma MA, Cordell JR, Chapman JW (2008) Distribution of the invasive New Zealand mudsnail (Potamopyrgus antipodarum) in the Columbia River Estuary and its first recorded occurrence in the diet of juvenile Chinook salmon (Oncorhynchus tshawytscha). Biol Invasions 10:13811388
Bottom DL, Jones KK (1990) Species composition, distribution, and invertebrate prey of fish assemblages in the Columbia River Estuary. Prog Oceanogr 25:243-270

Brenneis VEF, Sih A, de Rivera C (2010) Coexistence in the intertidal: interactions between the non-indigenous New Zealand mud snail Potamopyrgus antipodarum and the native estuarine isopod Gnorimosphaeroma insulare. Oikos 119:1755-1764

Bruce RL, Moffitt CM (2005) Survival of New Zealand Mudsnails (Potamopyrgus antipodarum) in the gastrointestinal tract of Rainbow Trout (Oncorhynchus mykiss). In: 4th New Zealand Mudsnail Conference, Montana State University, Bozeman

Bruno J, Stachowicz J, Bertness M (2003) Inclusion of facilitation into ecological theory. Trends Ecol Evol 18:119-125

Chesson J (1983) The estimation and analysis of preference and its relationship to foraging models. Ecology 64:1297-1304

Davidson TM, Brenneis VEF, de Rivera C, Draheim R, Gillespie GE (2008) Northern range expansion and coastal occurrences of the New Zealand mud snail Potamopyrgus antipodarum (Gray, 1843 ) in the northeast Pacific. Aquat Invasions 3:349-353

Davis MA (2003) Biotic globalization: does competition from introduced species threaten biodiversity? Bioscience 53:481-489

Duffy EJ (2003) Early marine distribution and trophic interactions of juvenile salmon in Puget Sound. University of Washington, Seattle

Gerard C, Blanc A, Costil K (2003) Potamopyrgus antipodarum (Mollusca : Hydrobiidae) in continental aquatic gastropod communities: impact of salinity and trematode parasitism. Hydrobiologia 493:167-172

Hall RO, Dybdahl MF, VanderLoop MC (2006) Extremely high secondary production of introduced snails in rivers. Ecol Appl 16:1121-1131

Hanson P (1997) Fish bioenergetics 3.0. University of Wisconsin System Sea Grant Institute, Center for Limnology, Wisconsin

Holt RD (1977) Predation, apparent competition, an the structure of prey communities. Theor Popul Biol 12:197-229

Holt RD, Kotler BP (1987) Short-term apparent competition. Am Nat 130:412-430

Jardine T, McGeachy S, Paton C, Savoie M, Cunjak R (2003) Stable isotopes in aquatic systems: sample preparation, analysis, and interpretation. Canadian Manuscript Report of Fisheries and Aquatic Sciences, Sacramento, p 39

McCarter NH (1986) Food and energy in the diet of brown and rainbow trout from Lake Benmore, New Zealand. NZ J Mar Fresh Res 20:551-559

Noonburg E, Shuter B, Abrams P (2003) Indirect effects of zebra mussels (Dreissena polymorpha) on the planktonic food web. Can J Fish Aquat Sci 60:1353-1368

Phillips DL, Gregg JW (2001) Uncertainty in source partitioning using stable isotopes. Oecologia 127:171-179

Pinkas L, Oliphant MS, Iverson ILK (1971) Food habits of Albacore, Bluefin Tuna, and Bonito in California waters. In: Fish Bulletin, vol 152. California Department of Fish and Game, Sacramento

Post DM (2002) Using stable isotopes to estimate trophic position: models, methods, and assumptions. Ecology 83:703-718

Rodriguez L (2006) Can invasive species facilitate native species? Evidence of how, when, and why these impacts occur. Biol Invasions 8:927-939

Rowles AD, O’Dowd DJ (2009) New mutualism for old: indirect disruption and direct facilitation of seed dispersal following Argentine ant invasion. Oecologia 158:709-716

Sagar PM, Glova GJ (1995) Prey availability and diet of juvenile brown trout (Salmo trutta) in relation to riparian willows (Salix spp.) in three New Zealand streams. NZ J Mar Freshw Res 29:527-537

Savidge J (1987) Extinction of an island forest avifauna by an introduced snake. Ecology 68:660-668 
Sax D, Stachowicz JJ, Brown JH, Bruno JG, Dawson MN, Gaines SD, Grosberg RK, Hastings A, Holt RD, Mayfield MN, O’Conner MI, Rice WR (2007) Ecological and evolutionary insights from species invasions. Trends Ecol Evol 22:465-470

Schreiber ESG, Lake PS, Quinn GP (2002) Facilitation of native stream fauna by an invading species? Experimental investigations of the interaction of the snail, Potamopyrgus antipodarum (Hydrobiidae) with native benthic fauna. Biol Invasions 4:317-325

Vander Zanden MJ, Cabana G, Rasmussen JB (1997) Comparing trophic position of freshwater fish calculated using stable nitrogen isotope ratios $\left(\delta^{15} \mathrm{~N}\right)$ and literature dietary data. Can $\mathrm{J}$ Fish Aquat Sci 54:1142-1158
Vinson M, Baker MA (2008) Poor growth of rainbow trout fed New Zealand mud snails Potamopyrgus antipodarum. North Am J Fish Manag 28:701-709

White EM, Wilson JC, Clarke AR (2006) Biotic indirect effects: a neglected concept in invasion biology. Divers Distrib 12:433-455

Woodward G, Papantoniou G, Edwards F, Lauridsen RB (2008) Trophic trickles and cascades in a complex food web: impacts of a keystone predator on a stream community structure and ecosystem processes. Oikos 117:683-692

Zhang Y, Richardson JS (2007) Unidirectional prey-predator facilitation: apparent prey enhance predators' foraging success on cryptic prey. Biol Lett 3:348-351 